\title{
Placental Transfer of Intravascular Coagulation between Mother and Fetus
}

\author{
A. J. Bishop, L. G. Israels, V. Chernick, and E. D. Israels ${ }^{[122]}$ \\ Departments of Pediatrics and Medicine, University of Manitoba, and the Clinical Investigation Units of Winnipeg Children's \\ Hospital and Winnipeg General Hospital, Winnipeg, Manitoba, Canada
}

\begin{abstract}
Extract
Pregnant sheep of 110-140 days' gestation were used to determine the effect of intravascular coagulation in the mother upon her fetus and the effect of intravascular coagulation in the fetus upon its mother. Because fetal lambs can be delivered and left attached to the mothers via the umbilical cord without placental separation, coagulation studies on a mother and her corresponding fetus could be done simultaneously. When intravascular coagulation was induced in the mothers by administering thromboplastin infusions intravenously, the attached fetal lambs also developed intravascular coagulation with decreased levels in platelets, fibrinogen, and factor $\mathrm{V}$, and prolongation of prothrombin, thrombin, and partial thromboplastin times. When intravascular coagulation was induced in fetal lambs, the dam had a drop in platelet count, a minimal drop in fibrinogen levels, and the appearance of fibrin breakdown products in serum and urine.

The factor or factors that crossed the placenta initiating this transfer of coagulation abnormalities are not known. It has been demonstrated that the transfer was not due to fibrin or fibrinogen breakdown products, nor to the infused thromboplastin, and that the trauma of surgery or hypoxia did not contribute to the coagulation abnormalities. The mothers consistently developed fibrin breakdown products in the serum and urine when intravascular coagulation was induced. This was in contrast to the results observed in fetal lambs, which, with one exception, did not show evidence of fibrin breakdown products in serum or urine under identical experimental conditions. These observations suggest the fibrinolytic system of the fetus is inefficient compared with that of the adult; this could be a considerable disadvantage in the presence of intravascular coagulation.
\end{abstract}

\section{Speculation}

As a result of intravascular coagulation in the mother or the fetus a stimulus is produced on the opposite side of the placental barrier resulting in similar changes in the placental partner. This mechanism may be of significance in the etiology of fetal death in eclampsia.

\section{Introduction}

Defects in hemostasis have been described in women with toxemia of pregnancy with preeclampsia or eclampsia $[28,45,54,68,74,75,94,99]$, abruptio placentae $[4,7,29,33,39,53,69,72,76,82,87,98$, 111], amniotic fluid embolism $[53,68,83,86,88,99$, 102], retention of a dead fetus $[36,53,67,68,70,71$, $73,89,99,109,113]$, and sepsis $[53,68,99]$. The pathogenesis of coagulation abnormalities has been 
attributed to acute or chronic intravascular coagulation $[29,53,57,58,68,72,92,94,97,99,106,108]$. There is little information, however, regarding necropsy findings in stillborns or the coagulation status of newborns surviving these pregnancies.

That intravascular coagulation occurs in the neonate has only recently been recognized [47], and the concept that intravascular coagulation may occur in the fetus in utero is relatively new $[19,61]$. It is significant that a number of newborns with intravascular coagulation recognized within $48 \mathrm{hr}$ of birth and stillborns with the pathological findings of disseminated intravascular coagulation are from pregnancies complicated by sepsis, toxemia with preeclampsia or eclampsia [12, $18,38,47]$, partial or complete abruptio placenta [31, $104,105]$, or retention of a dead macerated twin [10, $61,90]$. All of these aberrations are known to be associated with intravascular coagulation in the mothers. Information regarding the coagulation status of the mothers of these infants is strikingly absent. This association of coagulation disorders in the mother or fetus associated with disease on the other side of the placenta strongly suggests that the stimulus is capable of crossing the placenta. However, as simultaneous studies of the coagulation system are difficult to obtain in mother and fetus under these clinical circumstances, an animal system was used to study the effects of intravascular coagulation induced in the mother or fetus on its placental partner.

Since a lamb may be delivered and left attached to its mother via the umbilical cord without placental separation for many hours, pregnant sheep of 110-140 days' gestation were used to determine the effect of intravascular coagulation in the mother upon her fetus, and the effect of intravascular coagulation in the fetus upon its mother.

\section{Materials and Methods}

\section{Fibrinogen}

Adult sheep fibrinogen was prepared from citrated plasma ( 1 part $3.8 \%$ sodium citrate to 9 parts blood) by the ethanol fractionation method of Blomback and Blomback [15] followed by glycine extraction and tannic acid precipitation as described by Barnhart and Forman [9]. This procedure yielded fibrinogen at a concentration of $1400-1800 \mathrm{mg} / 100 \mathrm{ml}$ containing 90 $92 \%$ clottable protein. Total protein and the clottable fractions were determined by the method of Blomback [14]. Fetal fibrinogen was prepared by the glycine precipitation method of Kazal [44], which yielded fibrinogen preparations at concentrations of $350-600$ $\mathrm{mg} / 100 \mathrm{ml}$ with $100 \%$ clottable protein.

\section{Fibrinogen Breakdown Products}

Breakdown products were prepared from adult fibrinogen by streptokinase digestion [100]. Human euglobulin was added to the system as a source of "proactivator." The digestion was continued for 18-24 hr. On immunoelectrophoresis these "late products" of fibrinogen digestion showed only two lines with $\alpha$ and $\beta$ mobilities designated, respectively, as $E$ and $D$ by Nussenzweig et al. [64]. Fetal and adult $D$ and $\mathrm{E}$ were purified as previously described [85]. Fibrinogen breakdown products in the serum and urine were identified immunologically by Ouchterlony gel diffusion [115] using adult and fetal antifibrinogen, anti-D, and anti-E. Serum for fibrin breakdown products was collected in tubes containing thrombin and $\epsilon$-aminocaproic acid (EACA), and urine was collected in bottles containing EACA as previously described [41].

\section{Specific Antisera}

Antisera to both adult and fetal fibrinogen, D and E breakdown products were prepared as described previously [85].

\section{Coagulation Tests and Factor Assays}

Blood was collected into tubes containing acid citrate and EACA [85]. For plasminogen assays, blood collected without EACA was used. The thrombin time (1 unit/ $\mathrm{ml}$ ) was determined by the method of Fletcher [34] and the partial thromboplastin time by a modification of the method of Proctor and Rapaport [77] substituting celite for kaolin. One-stage prothrombin time and factor $\mathrm{V}$ assays were determined by the methods of Quick [78, 79]. The ewes' control samples were considered $100 \%$ for factor V. Plasma fibrinogen was assayed by the modification [6] of the method described by Ratnoff and Menzie [81], and plasminogen by the method of Alkjaersig and associates [2].

\section{Animal System}

Surgery. Anesthesia was induced in the ewe with Nembutal, $20-30 \mathrm{mg} / \mathrm{kg}$ administered intravenously, and light anesthesia was maintained throughout the experiments with intermittent injections of 75-150 mg Nembutal. Fetal lambs were delivered by cesarean section, and umbilical cords were left attached. The lambs were not allowed to breathe air, their heads being immersed in warm isotonic saline. Catheters were inserted into the jugular or femoral vein and the carotid or femoral artery of the fetus, and in the jugular vein and carotid artery of the ewe. The catheters were kept patent with an $0.85 \% \mathrm{NaCl}$ solu- 
tion. All infusions were given intravenously, and the blood was collected for coagulation studies by arterial sampling. Adult and fetal samples were collected simultaneously.

\section{Infusions}

Thromboplastin. Intravascular coagulation was induced with thromboplastin infusions $(8-12 \mathrm{ml} / \mathrm{kg}$, ewe; $10-15 \mathrm{ml} / \mathrm{kg}$, fetus) given over a period of 10-15 min. Thromboplastin was prepared from fresh human brain [13] suspended in saline. The saline suspensions gave a prothrombin time of $11.5-14 \mathrm{sec}$.

Heparin. Heparin $(175 \mathrm{mg} / \mathrm{kg})$ was administered intravenously to the ewes and heparinization maintained by continuous infusion of $50 \mathrm{mg} / \mathrm{kg}$ heparin in $300 \mathrm{ml}$ of $0.85 \% \mathrm{NaCl}$ solution at the rate of $50-100$ $\mathrm{ml} / \mathrm{hr}$. Fetal lambs were given $300 \mathrm{mg} / \mathrm{kg}$ heparin intravenously and heparinization maintained with a continuous infusion of $300 \mathrm{mg} / \mathrm{kg}$ heparin in $150 \mathrm{ml}$ of $0.85 \% \mathrm{NaCl}$ solution at the rate of $5-10 \mathrm{ml} / \mathrm{hr}$.

Fibrinogen breakdown products. The late products of fibrinogen degradation obtained from $300 \mathrm{mg}$ purified adult fibrinogen suspended in $100 \mathrm{ml}$ saline were infused into the mothers. Breakdown products from $150-300 \mathrm{mg}$ adult fibrinogen suspended in $25-35 \mathrm{ml}$ saline were infused into the fetal lambs.

Experimental. The animals were divided into the following groups. Group I: Thromboplastin infusions (11): A. thromboplastin infused into the mother (6); B. thromboplastin infused into the fetus (3); C. thromboplastin infused into a 2. and a 7-week-old lamb (2). Group II: Heparin plus thromboplastin (2). These animals were heparinized as described. When the partial thromboplastin time was prolonged to $2 \mathrm{~min}$ and the whole blood clotting time was in excess of $30 \mathrm{~min}$, the thromboplastin infusion was started. A. Heparin followed by thromboplastin into mother; B. heparin followed by thromboplastin into fetus. Group III: Infusions of late products of fibrinogen degradation products (5): A. fibrinogen breakdown products infused into the mother (2); B. fibrinogen breakdown products infused into the fetus (3). Group IV: Animals subjected to identical anesthesia and surgical methods as those in groups $I, I I$, and $I I I$ but not infused (3).

\section{Results}

Comparison of Coagulation Tests and Factor Levels in Ewes and Their Fetal Lambs

Table I compares the prothrombin, partial thromboplastin and thrombin times, plasminogen, fibrinogen, factor $V$ levels, and platelet counts of each mother and her corresponding fetus. These are control samples taken prior to any infusion.

The prothrombin and partial thromboplastin times of the fetal lambs were invariably longer than those of their dams. This was also true for the thrombin times in most animals. The fibrinogen, plasminogen, and factor $V$ assays were lower in the fetus. These findings are in agreement with values reported in human newborns $[1,3,26,35,42,51,63]$.

There was a wide variation in platelet counts in both the mother and fetus, but platelet counts in fetal blood did not differ significantly from maternal values. The fetal lambs had gestational ages of 110-140 days; however, the numbers were insufficient to compare fetal values at different gestational ages.

\section{Thromboplastin Infusion (Group I)}

Thromboplastin infusion into the mother. As seen in Figure 1, when thromboplastin was infused into the mother, intravascular coagulation was quickly induced, as evidenced by the rapid decrease in platelets, marked increase in partial thromboplastin, thrombin, and prothrombin times. Fibrinogen levels decreased from 340 to $15 \mathrm{mg} / 100 \mathrm{ml}$. Factor V levels also decreased from 100 to $20 \%$. Fibrin breakdown products were present in both the urine and serum of postinfusion samples.

Figure 2 illustrates the coagulation studies in the fetus of the mother shown in Figure 1. Within $25 \mathrm{~min}$ of starting the infusion into the mother, there was a drop in the fetal platelet count. The thrombocytopenia became most marked $45 \mathrm{~min}$ postinfusion. Two hours postinfusion, the partial thromboplastin and thrombin times were prolonged, and there was a drop in fibrinogen levels. The coagulation abnormalities were most marked $3 \mathrm{hr}$ postinfusion, and at this time the prothrombin time was also prolonged. The factor $\mathrm{V}$ level fell from $40 \%$ to less than $10 \%$. Fibrin breakdown products were not detectable in the lamb's serum or urine using both fetal and adult antifibrinogen, anti-D, and anti-E. Fragmentation of red blood cells was present in the postinfusion peripheral blood smears of both mother and fetus [25, 91]. There was no significant change in hematocrit between preinfusion samples and the final samples withdrawn in each experiment. Six such experiments were performed with similar findings. Results of the other five experiments are given in Table II.

Thromboplastin infusion into fetus. There were three experiments in which the fetus was infused with thromboplastin. The results are given in Table III and Figures 3 and 4. Figure 3 is an example of a twin 
Table I. Comparison of fetal and maternal control samples

\begin{tabular}{|c|c|c|c|c|c|c|c|c|c|c|c|c|c|c|}
\hline & \multicolumn{2}{|c|}{$\mathrm{PT}^{1}$} & \multicolumn{2}{|c|}{$\begin{array}{l}\text { PTT }^{1} \\
\text { sec }\end{array}$} & \multicolumn{2}{|c|}{$\mathrm{TT}^{1}$} & \multicolumn{2}{|c|}{$\begin{array}{c}\text { Factor } V, 2 \\
\%\end{array}$} & \multicolumn{2}{|c|}{$\begin{array}{l}\text { Fibrinogen, } \\
\mathrm{mg} / 100 \mathrm{ml}\end{array}$} & \multicolumn{2}{|c|}{$\begin{array}{l}\text { Plasminogen, casein } \\
\text { units } / \mathrm{ml}\end{array}$} & \multicolumn{2}{|c|}{$\begin{array}{l}\text { Platelets } / \mathrm{mm}^{2} \\
\quad\left(\times 10^{3}\right)\end{array}$} \\
\hline & $M^{\prime}$ & $\mathrm{F}$ & $\mathbf{M}$ & $\mathbf{F}$ & $\mathbf{M}$ & $\mathbf{F}$ & $\mathbf{M}$ & F & $\mathbf{M}$ & $\mathrm{F}$ & $\mathbf{M}$ & F & $\mathbf{M}$ & $\mathbf{F}$ \\
\hline & 15 & 23 & 29 & 49 & 35 & 42 & 100 & 48 & 512 & 118 & & & 800 & 565 \\
\hline & 14 & 22 & 16 & 22 & 29 & 37 & 100 & 40 & 348 & 129 & & 0.52 & 482 & 570 \\
\hline & 13 & 27 & 24 & 33 & 32 & 40 & 100 & 72 & 509 & 115 & & 0.07 & 607 & 504 \\
\hline & 14 & 24 & 21 & 28 & 28 & 44 & 100 & 30 & 424 & 112 & 2.3 & 0.84 & 371 & 420 \\
\hline & 13 & 16 & 18 & 45 & 28 & 36 & 100 & 80 & 544 & 202 & & 0.9 & 168 & 561 \\
\hline & 13 & 22 & 21 & 30 & 31 & 43 & 100 & 72 & 488 & 78 & & 0.62 & 363 & 400 \\
\hline & 15 & 22 & 33 & 58 & 32 & 37 & 100 & 64 & 533 & 117 & & 0.62 & 444 & 335 \\
\hline & 12 & 19 & 33 & 48 & 30 & 31 & 100 & 54 & 842 & 140 & & 0.93 & 520 & 360 \\
\hline & 13 & 21 & 16 & 30 & 37 & 54 & 100 & 58 & 267 & 107 & 1.5 & 1.0 & 718 & 470 \\
\hline & 16 & 21 & 16 & 36 & 34 & 35 & 100 & 56 & 263 & 157 & 1.9 & 0.7 & 452 & 576 \\
\hline & 12 & 20 & 28 & 44 & 23 & 26 & 100 & 39 & 379 & 199 & 2.5 & 0.8 & 1,094 & 580 \\
\hline & 14 & 20 & 29 & 39 & 29 & 28 & 100 & 62 & 379 & 157 & 2.9 & 0.6 & 291 & 595 \\
\hline & 12 & 26 & 20 & 35 & 25 & 34 & 100 & 80 & 368 & 135 & 2.3 & 0.6 & 612 & 532 \\
\hline & 13 & 19 & 40 & 45 & 30 & 33 & 100 & 100 & 320 & 152 & 1.8 & 0.5 & 624 & 481 \\
\hline & 12 & 18 & 34 & 41 & 27 & 29 & 100 & 100 & 528 & 216 & 2.7 & 1.0 & 381 & 610 \\
\hline & 14 & 21 & 25 & 41 & 24 & 32 & 100 & 78 & 331 & 157 & 1.7 & 0.82 & 467 & 564 \\
\hline & 14 & 21 & 24 & 34 & 25 & 29 & 100 & 64 & 623 & 129 & 2.9 & 0.7 & 622 & 487 \\
\hline Mean & 13.5 & 21 & 25 & 39 & 29 & 36 & & 65 & 450 & 142 & 2.3 & 0.70 & 530 & 506 \\
\hline
\end{tabular}

$1 \mathrm{PT}=$ prothrombin time; PTT $=$ partial thromboplastin time; $\mathrm{TT}=$ thrombin time.

2 The ewes' control sample in each experiment was considered as $100 \%$.

' $\mathrm{M}$ : mother; $\mathrm{F}$ : fetus.

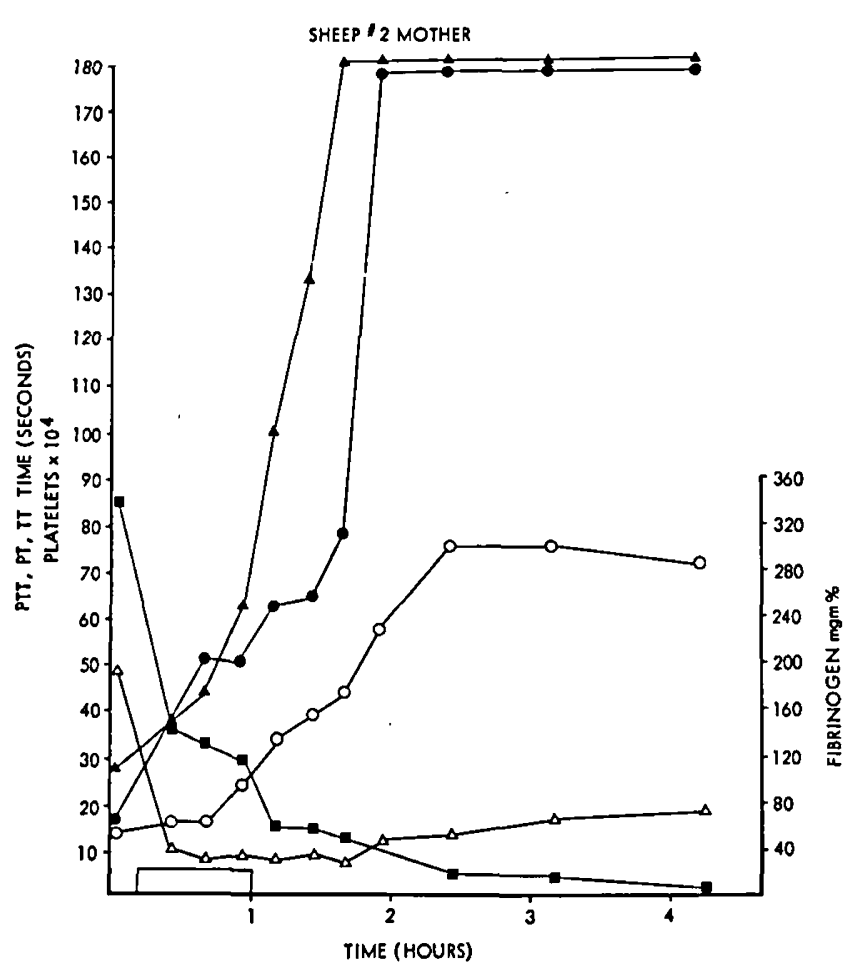

Fig. 1. Mother was infused with thromboplastin, $12 \mathrm{ml} / \mathrm{kg}$, for $50 \mathrm{~min}$ (bar). $\bullet$ : Partial thromboplastin time. $\Delta$ : Thrombin tiıe. $\square$ : Fibrinogen. $O$ : Prothrombin time. $\triangle$ : Platelets. preparation. Fetus $A$ was delivered in the usual man. ner, and fetus $B$ was left in utero. Thromboplastin was infused into fetus $A$, and intravascular coagulation was induced as reflected by a decrease in the platelet count and fibrinogen level and an increase in prothrombin, partial thromboplastin, and thrombin times.

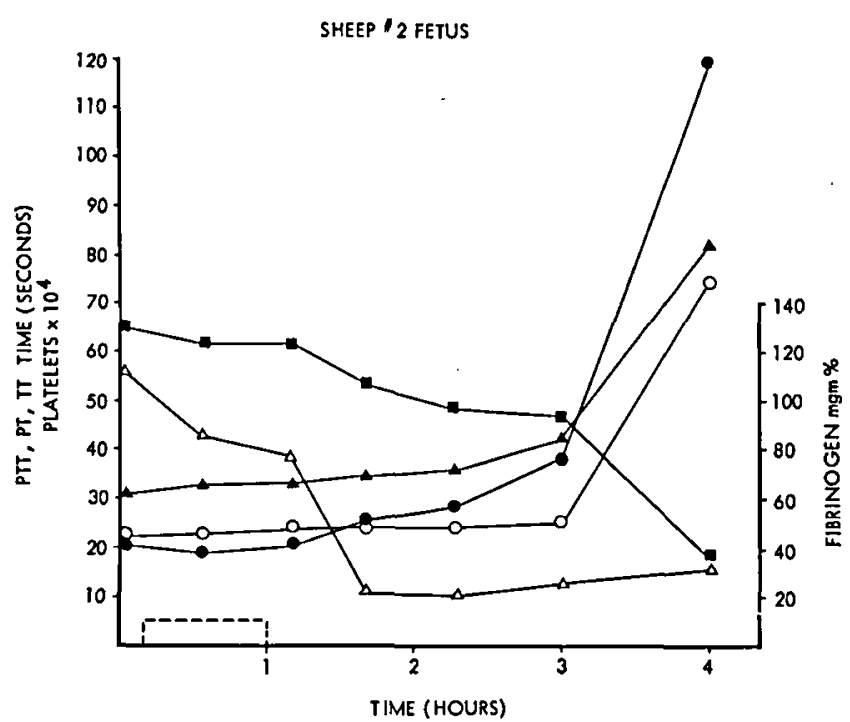

Fig. 2. Fetus of the mother in Figure 1. The bar indicates the thromboplastin infusion into the mother. Symbols as in Figure 1. 
Table II. Mother infused with thromboplastin: Simultaneous coagulation studies in fetus and mother ${ }^{1}$

\begin{tabular}{|c|c|c|c|c|c|c|c|c|c|c|c|c|c|c|c|c|}
\hline \multirow{2}{*}{ Exp. no. } & \multicolumn{2}{|c|}{ PT } & \multicolumn{2}{|c|}{$\begin{array}{r}\text { PTT } \\
\text { sec }\end{array}$} & \multicolumn{2}{|c|}{ TT } & \multicolumn{2}{|c|}{$\begin{array}{l}\text { Fibrinogen, } \\
\mathrm{mg} / 100 \mathrm{ml}\end{array}$} & \multicolumn{2}{|c|}{$\begin{array}{l}\text { Platelets/mm } \\
\left(\times 10^{3}\right)\end{array}$} & \multicolumn{2}{|c|}{ Factor V, \% } & \multicolumn{4}{|c|}{ Serum } \\
\hline & Pre & Post & Pre & Post & Pre & Post & Pre & Post & Pre & Post & Pre & Post & Pre & Post & Pre & Post \\
\hline M-1 & 15 & 18 & 29 & 47 & 34 & 39 & 512 & 334 & 800 & 83 & 100 & 54 & - & + & - & + \\
\hline $\mathrm{F}-1$ & 22 & 34 & 49 & 67 & 41 & 50 & 118 & 81 & 575 & 209 & 48 & 28 & - & - & - & - \\
\hline M-2 & 14 & 72 & 16 & 180 & 29 & 180 & 348 & 16 & 482 & 78 & 100 & 19 & - & + & - & + \\
\hline $\mathrm{F}-2$ & 22 & 75 & 21 & 120 & 32 & 86 & 129 & 33 & 570 & 102 & 40 & 6 & - & - & - & - \\
\hline M-3 & 13 & 14 & 17 & 28 & 27 & 37 & 544 & 258 & 168 & 40 & 100 & 100 & - & + & - & + \\
\hline F-3 & 16 & 22 & 32 & 45 & 35 & 47 & 202 & 78 & 561 & 70 & 80 & 44 & - & - & - & - \\
\hline M-4 & 14 & 17 & 21 & 39 & 28 & 44 & 424 & 278 & 371 & 84 & 100 & 40 & - & + & - & + \\
\hline F-4 & 24 & 26 & 28 & 42 & 44 & 62 & 112 & 78 & 420 & 73 & 30 & 20 & - & - & - & - \\
\hline M-5 & 13 & 15 & 21 & 32 & 31 & 34 & 488 & 308 & 363 & 264 & 100 & 80 & - & + & - & + \\
\hline F-5 & 22 & 52 & 30 & 210 & 43 & 183 & 112 & 28 & 400 & 231 & 72 & 24 & - & - & - & - \\
\hline M-6 & 13 & 34 & 17 & 32 & 25 & 39 & 612 & 168 & 638 & 246 & 100 & 48 & - & + & - & + \\
\hline$F-6$ & 21 & 47 & 32 & 68 & 35 & 77 & 129 & 58 & 478 & 26 & 48 & 20 & - & - & - & - \\
\hline
\end{tabular}

1 F : fetus; M : mother; PT : prothrombin time; PTT : partial thromboplastin time; TT: thrombin time; FBP : fibrin breakdown products; Pre: preinfusion control sample; Post: maximal change in postinfusion samples; $\mathrm{M}-\mathrm{l}$ and $\mathrm{M}-3$ to $6: 8 \mathrm{ml} / \mathrm{kg}$ thromboplastin over 50 $\mathrm{min} ; \mathrm{M}-2: 12 \mathrm{ml} / \mathrm{kg}$ thromboplastin over $50 \mathrm{~min}$.

Table III. Thromboplastin infused into fetus: Simultaneous coagulation studies in mother and fetus ${ }^{1}$

\begin{tabular}{|c|c|c|c|c|c|c|c|c|c|c|c|c|c|c|c|c|}
\hline \multirow{2}{*}{ Exp. no. } & \multicolumn{2}{|c|}{ PT } & \multicolumn{2}{|c|}{$\begin{array}{r}\text { PTT } \\
\text { sec }\end{array}$} & \multicolumn{2}{|c|}{$\mathrm{Tr}$} & \multicolumn{2}{|c|}{$\begin{array}{l}\text { Fibrinogen, } \\
\mathrm{mg} / 100 \mathrm{ml}\end{array}$} & \multicolumn{2}{|c|}{$\begin{array}{l}\text { Platelets } / \mathrm{mm}^{2} \\
\quad\left(\times 10^{2}\right)\end{array}$} & \multicolumn{2}{|c|}{ Factor V, \% } & \multicolumn{4}{|c|}{ Serum $\quad$ FBP } \\
\hline & Pre & Post & Pre & Post & Pre & Post & Pre & Post & Pre & Post & Pre & Post & Pre & Post & Pre & Post \\
\hline$F-10$ & 19 & 34 & 48 & 77 & 31 & 40 & 219 & 140 & 360 & 120 & 54 & 21 & - & - & - & - \\
\hline M-10 & 12 & 12 & 33 & 32 & 30 & 31 & 842 & 589 & 520 & 414 & 100 & 100 & - & + & - & + \\
\hline$F-11$ & 22 & 49 & 55 & 180 & 32 & 67 & 117 & 55 & 335 & 182 & 44 & 3 & - & - & - & - \\
\hline M-11 & 15 & 15 & 33 & 33 & 32 & 32 & 533 & 488 & 488 & 368 & 100 & 100 & - & + & - & + \\
\hline F-13a & 20 & 43 & 44 & 146 & 25 & 35 & 199 & 124 & 580 & 212 & 42 & 11 & - & + & - & + \\
\hline $\mathrm{b}$ & 20 & & 44 & & 25 & & 180 & & 600 & 74 & 48 & & - & - & - & - \\
\hline M-13 & 12 & 14 & 28 & 30 & 23 & 25 & 380 & 284 & 1,094 & 476 & 100 & 100 & - & + & - & + \\
\hline
\end{tabular}

${ }_{1}$ Abbreviations as in Table II. F-10: $10 \mathrm{ml} / \mathrm{kg}$ over $20 \mathrm{~min}$; F-11, 13a, $13 \mathrm{~b}: 15 \mathrm{ml} / \mathrm{kg}$ over 5-10 min.

Factor V decreased from 40 to $10 \%$. Fetus $A$ was killed after $1.5 \mathrm{hr}$, and fetus $B$ was delivered. Fetus $B$ was then infused with thromboplastin. It will be noted that the preinfusion values of platelets, fibrinogen, prothrombin, partial thromboplastin, and thrombin times were similar to the control values for fetus $A$.

Figure 4 gives the results in the mother of the twins shown in Figure 3 . Within $5 \mathrm{~min}$ of completing the thromboplastin infusion into fetus $A$, there was a decrease in the mother's platelet count. Over the next 2 $\mathrm{hr}$, no further decrease in platelet count occurred; other coagulation tests and factor levels remained essentially normal. Fifteen minutes after the infusion into fetus $B$ was complete, there was a further fall in the mother's platelet count and her fibrinogen level decreased from 380 to $284 \mathrm{mg} / 100 \mathrm{ml}$. Fibrin breakdown products appeared in the mother's serum $5 \mathrm{~min}$ after the thromboplastin infusion into fetus $A$ was completed and were present throughout the remainder of the experiment. Fibrin breakdown products were also found in the mother's urine.

Of the four fetal lambs infused with thromboplastin, in only one (twin $A$, Fig. 3) could fibrin breakdown products be identified in the serum or urine (Table III).

Thromboplastin infusion into the newborn. When thromboplastin was infused into a 2-week-old lamb (Fig. 5), intravascular coagulation was induced but fibrin breakdown products did not appear in the serum or urine. Similar results were obtained when thromboplastin was infused into a 7-week-old lamb.

\section{Heparin and Thromboplastin Infusions (Group II)}

Heparin and thromboplastin infusions into the mother. With the heparin regimen previously described, the mother's partial thromboplastin time was prolonged beyond $2 \mathrm{~min}$, and the whole blood clotting time was in excess of $30 \mathrm{~min}$. The partial thrombo- 


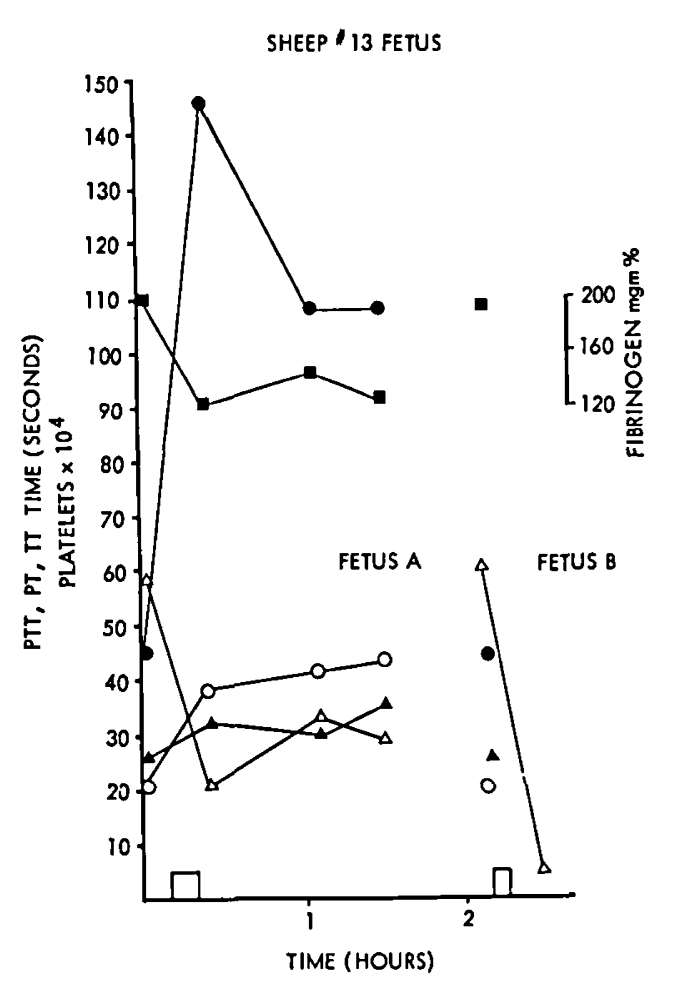

Fig. 3. Twin preparation; bars indicate the thromboplastin infusions into the fetal lambs (fetus $A, 15 \mathrm{ml} / \mathrm{kg}$ over a 10 -min period; fetus $\mathrm{B}, 15 \mathrm{ml} / \mathrm{kg}$ over a 5 -min period). Symbols as in Figure 1.

plastin time and whole blood clotting time of her fetus, however, were unchanged. When the heparinized mother was infused with thromboplastin, intravascular coagulation was not induced, and the coagulation tests and factor levels in her fetus remained normal.

Heparin and thromboplastin infusions in the fetus. When the fetus was heparinized, its partial thromboplastin time was prolonged beyond $2 \mathrm{~min}$ and its whole blood clotting time was longer than $1 \mathrm{hr}$. The mother's partial thromboplastin and whole blood clotting times remained unchanged. When the heparinized fetus was infused with thromboplastin, it did not develop intravascular coagulation, and the coagulation tests and factor levels of the attached mother were unchanged.

\section{Infusion of Late Products of Fibrinogen Degradation (Group III)}

Fibrinogen breakdown products infused into the mother. When the late products of fibrinogen digestion were infused into the mother, platelet counts, factor $\mathrm{V}$, and fibrinogen levels did not fall and partial thromboplastin, thrombin, and prothrombin times remained normal. The coagulation tests and factor levels in the attached fetal lambs remained unchanged. Fibrin breakdown products were identified in the serum and urine of the mothers but were not present in either the serum or the urine of their fetal lambs.

Fibrinogen breakdown products infused into the fetus. When the late products of fibrinogen degradation were infused into the fetus (Fig. 6), there was a marked decrease in the platelet count but only minimal changes in the coagulation tests. Factor $\mathrm{V}$ levels did not decrease. The coagulation status of the mother remained normal. Fibrin breakdown products were present in both the serum and urine of the infused fetus but were not present in either the serum or urine of the mother. Table IV summarizes the findings in the other two animals of this group.

\section{Anesthesia and Surgery without Infusions (Group IV)}

These animals had anesthesia and surgery identical with the experimental groups and the same amounts of blood were withdrawn for coagulation studies. Fibrin breakdown products did not appear in the serum or urine and the partial thromboplastin, prothrombin, and thrombin times remained normal; this applied to both fetus and mother. One animal was made intermittently anoxic by breathing nitrogen so that arterial $\mathrm{Po}_{2}$ decreased from 120 to $20 \mathrm{~mm}$ for 5 -min periods without producing any abnormality in the coagulation

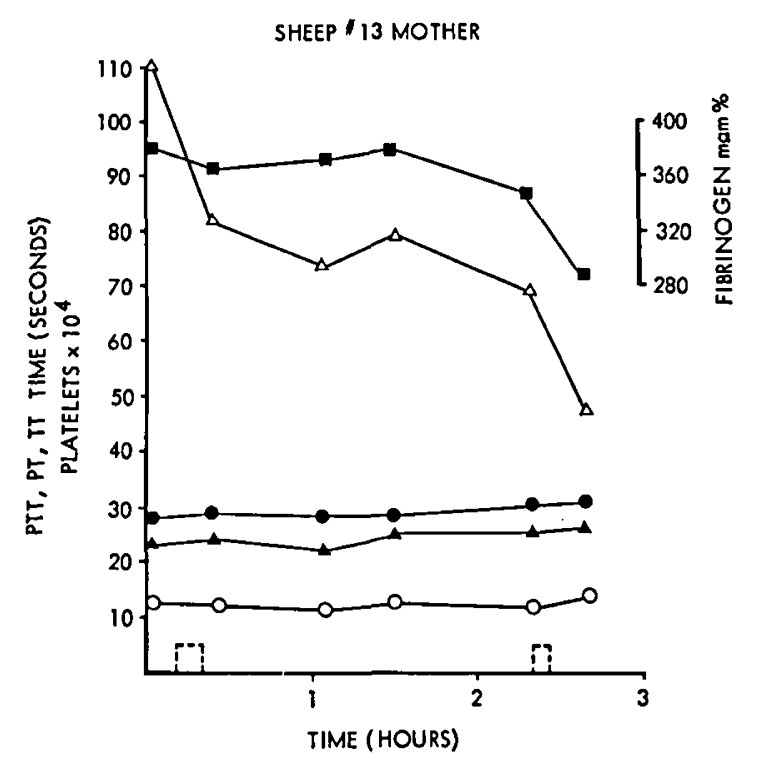

Fig. 4. Mother of the twins shown in Figure 3. The bars indicate the thromboplastin infusions into the fetal lambs. Symbols as in Figure 1. 
status of the mother or fetus. One fetus was rendered anoxic via intermittent cord clamping, but neither fetus nor mother developed any coagulation abnormalities.

\section{Discussion}

It has been postulated by Schneider [92, 95, 96] and others $[53,65,76$,$] that the bleeding diathesis seen in$ parturient women with abruptio placenta is initiated by massive infusion of decidual thromboplastin into

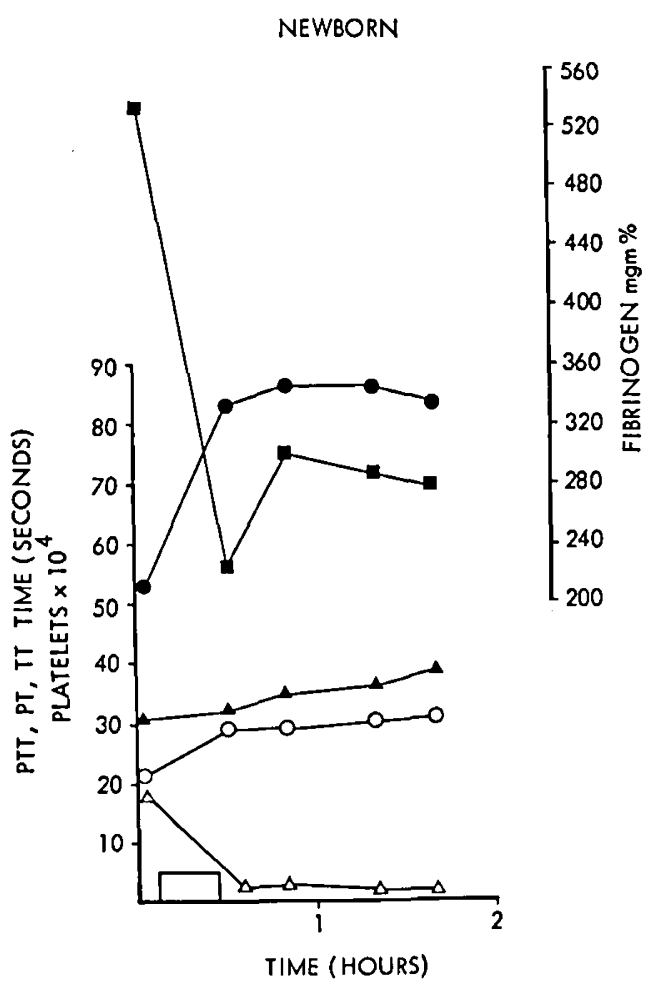

Fig. 5. Thromboplastin infused into a 2-week-old lamb (10 $\mathrm{ml} / \mathrm{kg}$ over a $25-\mathrm{min}$ period) as indicated by the bar. Symbols as in Figure 1.

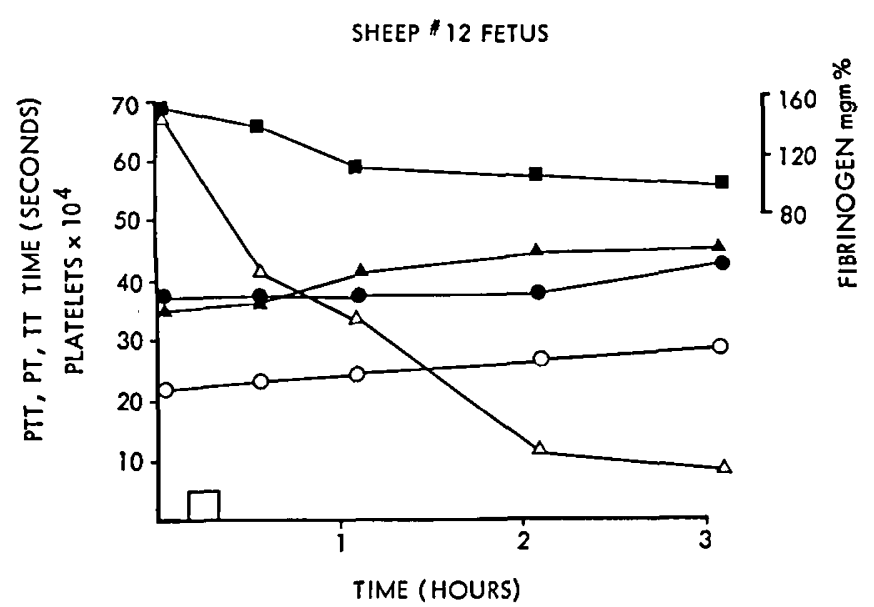

Fig. 6. Bar indicates fibrinogen breakdown products infused into the fetus. Symbols as in Figure 1.

the mother's circulation from rupture of the decidual plate at the time of placental separation. The possibility of this agent entering the fetal circulation, however, was not mentioned. Intravascular coagulation and the generalized Shwartzman reaction may also be produced in animals by trauma to the placenta $[24,93]$, and intravascular coagulation has been reported in a rabbit following spontaneous premature separation of the placenta [5]. Although there are numerous reports in the literature of coagulation abnormalities in women with abruptio placenta, little mention is made of the coagulation status of the infants who survived this complication or the pathological findings in stillborns.

Similarly, intravascular coagulation following amniotic fluid embolism is well documented [68, 84, 99], but, again, information concerning the fetus is lacking. In this situation, the thromboplastic substance responsible for the coagulation abnormalities is thought to be the debris and particulate matter of the amniotic fluid since amniotic fluid free of this material is not thromboplastic $[107,112]$. In pregnancies complicated

Table IV. Fetal lambs infused with fibrinogen breakdown products: Simul taneous coagulation studies in fetus and mother ${ }^{1}$

\begin{tabular}{|c|c|c|c|c|c|c|c|c|c|c|c|c|c|c|c|c|}
\hline \multirow{2}{*}{ Exp. nn. } & \multicolumn{2}{|c|}{$\mathbf{P T}$} & \multicolumn{2}{|c|}{$\begin{array}{r}\text { PTT } \\
\text { sec }\end{array}$} & \multicolumn{2}{|c|}{ TT } & \multicolumn{2}{|c|}{$\begin{array}{l}\text { Fibrinogen, } \\
\mathrm{mg} / 100 \mathrm{ml}\end{array}$} & \multicolumn{2}{|c|}{$\begin{array}{l}\text { Platelets } / \mathrm{mm}^{2} \\
\left(\times 10^{2}\right)\end{array}$} & \multicolumn{2}{|c|}{ Factor V, \% } & \multicolumn{4}{|c|}{ Serum } \\
\hline & Pre & Post & Pre & Post & Pre & Post & Pre & Post & Pre & Post & Pre & Post & Pre & Post & Pre & Post \\
\hline F-7 & 20 & 25 & 38 & 52 & 28 & 37 & 157 & 112 & 593 & 121 & 62 & 60 & - & + & - & + \\
\hline M-7 & 13 & 12 & 29 & 29 & 30 & 32 & 379 & 370 & 291 & 266 & 100 & 100 & - & - & - & - \\
\hline F-8 & 21 & 31 & 30 & 49 & 54 & 62 & 106 & 89 & 470 & 40 & 58 & 44 & - & + & - & + \\
\hline M-8 & 13 & 13 & 16 & 19 & 37 & 35 & 267 & 298 & 718 & 686 & 100 & 100 & - & - & - & - \\
\hline F-12 & 21 & 28 & 37 & 43 & 35 & 44 & 157 & 101 & 676 & 108 & 56 & 42 & - & + & - & + \\
\hline M-12 & 16 & 16 & 16 & 20 & 33 & 32 & 292 & 314 & 452 & 514 & 100 & 100 & - & - & - & - \\
\hline
\end{tabular}

\footnotetext{
1 Abbreviations as in Table II.
} 
by prolonged retention of a dead fetus, the intravascular coagulation may be initiated by thromboplastic material from the placenta, macerated fetus, or amniotic fluid, and the coagulation abnormalities may be mild or severe [68]. The coagulation abnormalities in patients with toxemia, or with preeclampsia or with eclampsia have also been related to the generalized Shwartzman reaction and intravascular coagulation $[53,57]$.

In animal experiments a high rate of abortion and fetal death occurred when intravascular coagulation was induced in the mother with endotoxin $[53,56,58$, $116]$, progesterone [53, 103], or abnormal lipid diets $[53,55,62,114]$, and the placental changes seen in the animals were similar to those seen in human toxemias. McKay $e t$ al. [53] suggested that the process begins with changes in the trophoblast leading to focal thrombosis and infarction of maternal vascular channels. Trophoblastic damage increases with leakage of clotpromoting factors from the placenta producing thrombosis of decidual and uterine veins. The resultant congestion of the placenta may lead to bleeding into the decidua and uterine cavity, premature separation of the placenta, and fetal death, providing further thromboplastic material.

The infants of such complicated pregnancies may also develop coagulation abnormalities. Boyd (19-23) has described disseminated fibrin thromboembolism in stillborns, many of whom were from pregnancies complicated by toxemia, preeclampsia and eclampsia, and premature separation of the placenta. Coagulation studies were not available on these mothers. It was suggested that placental thromboplastin may be capable of entering the fetal circulation to cause a syndrome in the fetus similar to that found in maternal hypofibrinogenemia [21, 22]. Other reports of coagulation abnormalities or intravascular coagulation in the newborn from pregnancies complicated by toxemia, abruptio placenta, or amniotic fluid embolism have been made by Edson [31], Hathaway [38], Kennan (case 4) [45], Leissring [47], Valentine [105], Bloom [16], Bolen [18], and Stark [104].

Newborns with bilateral renal cortical necrosis and other findings associated with intravascular coagulation have been described by Moore [61], Reisman [90], and Bernirschke [10] all in association with a dead macerated twin. Bernirschke [10] postulated that fetofetal exchange of thromboplastic material from the dead fetus through vascular shunts in a monochorionic placenta was responsible for this syndrome. Bernstein [12] reported 11 cases of renal cortical necrosis in new- borns of mothers with preeclampsia, eclampsia, placenta previa, and uterine or uteroplacental hemorrhage.

In the present study, with pregnant sheep, it is evident that coagulation abnormalities in the mother were accompanied by similar changes in her fetus and coagulation abnormalities in the fetus affected the coagulation status of the mother. The induction of intravascular coagulation in pregnant ewes was rapidly followed by intravascular coagulation in the fetal lambs with a rapid drop in platelet count, prolongation of prothrombin, thrombin, and partial thromboplastin times, and a decrease in fibrinogen and factor $V$ levels. When intravascular coagulation was induced in the fetus, the mother showed a drop in platelet count and a minimal decrease in fibrinogen levels with minor changes in prothrombin, partial thromboplastin, or thrombin times. Animals undergoing the same anesthesia and surgical procedure with or without induced anoxia did not develop any of the coagulation abnormalities described in the fetus or the mother.

That the transfer of the coagulation abnormalities is not due to the infused thromboplastin crossing the placenta can be demonstrated by heparinization of the thromboplastin recipient. Since heparin does not cross the placental barrier [37], it is possible to anticoagulate either the mother or the fetus. If the infused thromboplastin crosses the placental barrier, the fetus of a heparinized thromboplastin-infused mother should develop evidence of intravascular coagulation. In such an experiment, however, the coagulation status of the fetus remained unchanged. Similarly, the mother of a heparinized thromboplastin-infused fetus did not develop any coagulation abnormalities. These experiments indicate that the transfer of the coagulation defect to the placental partner of a thromboplastin-infused mother or fetus is not the result of the infused thromboplastin crossing the placental barrier but requires active intravascular coagulation in the fetus or mother or at least on their corresponding sides of the placental vasculature.

The precise role played by the placenta is not known. In our animals there were no gross infarcts, hemorrhage, or separation of the placenta. Microscopic evaluation must await normal control studies of sheep placentas at varying gestational ages, especially in regard to trophoblastic degeneration and fibrin deposition. This information is available for human placentas [60].

It was also demonstrated that fibrinogen breakdown products do not cross the placental barrier. As shown 
in Table $\mathrm{V}$, when the late products of fibrinogen degradation were infused into the mother or the fetus, they were not detectable in the serum or urine of the noninfused placental partner, nor did the latter develop any coagulation abnormalities. Although fibrinogen breakdown products are not the responsible factor for the placental transfer of intravascular coagulation, the response of the fetal or adult recipient to the infused breakdown products was different. The thrombocytopenia induced in the fetus infused with late fibrinogen breakdown products was probably due to the platelet-aggregating effect of product $D$, as shown by Barnhart [8]. The slight decrease in fibrinogen and mild prolongation of thrombin, prothrombin, and partial thromboplastin times could also be a direct result of the infused late products of fibrinogen degradation which are capable of forming soluble complexes that interfere with the conversion of fibrinogen to fibrin by thrombin $[46,49,59]$. It is also possible that during platelet aggregation some platelet changes occurred, releasing platelet factors 3 or 4 [48] and thereby inducing mild intravascular coagulation in the fetus which was not severe enough to affect the mother's coagulation system. When the late products of fibrinogen degradation were infused into the mothers, there were no significant changes in their platelets or other aspects of their clotting system, nor were there any coagulation abnormalities in the attached fetal lambs. The difference in the response of the fetus and the adult to infusion of breakdown products may be related to the much higher dose per kilogram given to the fetal lambs.

It is of interest that fibrin breakdown products formed in vivo in the mother as a consequence of direct thromboplastin infusion or indirectly by thromboplastin infusion into the fetus also do not cross the placental barrier (Table V). It has been shown, with one exception, that the fetal lambs with intravascular coagulation, whether induced by direct thromboplastin infusion or thromboplastin infusion into the mothers, do not show fibrin breakdown products in either the serum or urine although the fetus is capable of renal clearance of these products. The fetus is not forming late breakdown products and clearing them via the placenta into the mother since the fibrinogen breakdown products do not cross the placental barrier. This is in contrast to the mothers, who invariably have fibrin breakdown products in both the serum and the urine under the same experimental conditions. These observations suggest that the fibrinolytic system of the fetus is inefficient compared with that of the adult. Similarly,
Table $V$. Appearance of fibrin breakdown products under different experimental conditions

\begin{tabular}{|c|c|c|c|c|}
\hline \multirow{2}{*}{ Infusion } & \multicolumn{2}{|c|}{ Mother } & \multicolumn{2}{|c|}{ Fetus } \\
\hline & Serum & Urine & Serum & Urine \\
\hline \multicolumn{5}{|l|}{ A. Thromboplastin } \\
\hline Into mother & $6 / 6^{1}$ & $6 / 6^{1}$ & $0 / 6^{1}$ & $0 / 6^{1}$ \\
\hline Into fetus & $3 / 3$ & $3 / 3$ & $1 / 4$ & $1 / 4$ \\
\hline \multicolumn{5}{|c|}{$\begin{array}{l}\text { B. Thromboplastin plus } \\
\text { heparin }\end{array}$} \\
\hline Into mother & $0 / 2$ & $0 / 2$ & $0 / 2$ & $0 / 2$ \\
\hline Into fetus & $0 / 2$ & $0 / 2$ & $0 / 2$ & $0 / 2$ \\
\hline \multicolumn{5}{|c|}{ C. Breakdown products } \\
\hline Into mother & $3 / 3$ & $3 / 3$ & $0 / 3$ & $0 / 3$ \\
\hline Into fetus & $0 / 4$ & $0 / 4$ & $4 / 4$ & $4 / 4$ \\
\hline
\end{tabular}

1 Results are ratios of the number of animals showing breakdown products to the number of animals in each experimental group.

lambs up to 7 weeks of age also did not develop fibrin breakdown products in serum or urine following thromboplastin infusion.

The reasons for this difference between the adult and fetal fibrinolytic systems are not known. The ratio of plasminogen to fibrinogen is not consistently lower in the fetus than in the adult, although absolute values of both fibrinogen and plasminogen are lower. When intravascular coagulation is induced in the fetus, the plasminogen level does decrease (Table VI). It is not known whether the plasminogen is being activated and converted to plasmin but is present in insufficient quantity to lyse the fibrinogen or fibrin formed, or if the plasminogen is not activated but simply decreased because of adsorption onto the fibrin [101]. The ratio of inhibitor to activator in the fetus is also not known. That the lytic system of human newborns is different from that of adults was first suggested by Boisvert [17]. He observed that blood clots from newborn infants, in contrast to those of their mothers, were resistant to lysis in the presence of streptococcal culture supernates. He

Table VI. Fetal lambs with in travascular coagulation: Comparison of pre- and postinfusion fibrinogen and plasminogen levels

\begin{tabular}{lllllll}
\hline & & \multicolumn{2}{c}{$\begin{array}{c}\text { Fibrinogen, } \\
\text { Eg/100 }\end{array}$} & & \multicolumn{2}{c}{$\begin{array}{c}\text { Plasminogen, } \\
\text { casein units/ml }\end{array}$} \\
\cline { 2 - 3 } & Pre & Post & & Pre & Post \\
\hline F-2 & 129 & 33 & & 0.6 & 0.2 \\
F-3 & 202 & 78 & & 0.9 & 0.7 \\
F-4 & 112 & 78 & & 0.8 & 0.3 \\
F-5 & 112 & 28 & & 0.8 & 0.3 \\
F-6 & 129 & 58 & & 0.6 & 0.1 \\
F-11 & 117 & 55 & & 0.6 & 0.0 \\
F-13a & 199 & 124 & & 1.1 & 0.8 \\
\hline
\end{tabular}


postulated the existence of a nonspecific inhibitor of fibrinolysis in the newborn. Since that time the reports on the lytic system of the newborn have been conflicting. Some $[11,27,30,32,43]$ reported increased fibrinolytic activity of cord blood; others $[66,80]$ reported decreased fibrinolytic activity. Boyd [19] also suggested decreased lytic activity of the fetus, and Zilliacus [117] stated that the lytic activity decreases with aging of the fetus. Some of the studies showing increased fibrinolytic activity in the newborns may well have been measuring fibrinolysis in vitro, unless the samples were collected in inhibitors of fibrinolysis such as bovine protease inhibitor [118] or c-aminocaproic acid [101]. This is particularly important when umbilical cord blood samples are used, since tissue activator of the fibrinolytic system may easily contaminate such specimens.

\section{Summary}

In pregnancies complicated by abruptio placenta, amniotic fluid embolism, toxemia with preeclampsia or eclampsia, and retention of a dead fetus, hemostatic defects due to intravascular coagulation may occur. There is indirect evidence that the infants of such pregnancies may also develop coagulation abnormalities. In the present study, using pregnant sheep as the animal model, intravascular coagulation was induced with thromboplastin infusions into the mother or the fetus, and both were studied simultaneously. These experiments have shown that acquired coagulation abnormalities can be transferred from the mother to her fetus and from the fetus to its mother. This transfer is not due to the infused thromboplastin nor fibrin breakdown products crossing the placental barrier but requires active intravascular coagulation in the recipient or the recipient's side of the placental vasculature. It is also suggested that the fibrinolytic system of the fetus is inefficient compared with that of the adult.

\section{References and Notes}

1. Aballu, A. J., and de Lamerens, S.: Coagulation changes in the neonatal period and in early infancy. Pediat. Clin. N. Amer., 9: 785 (1962).

2. Alkjaersig, N., Fletcher, A. P., and Sherry, S.: The mechanism of clot dissolution by plasmin. J. Clin. Invest., 38: 1086 (1959).

3. Ambrus, C.: Ontogeny of the fibrinolysin system and its role in the pathogenesis of hyaline membrane discase of infants. Fed. Proc., 25: 68 (1966).

4. AMris, C. J., AND KJeldsen, J.: Hemorrhagic diathesis due to abruptio placentae treated with Trasylol. Acta Obstet. Gynecol. Scand., 45: 180 (1966).
5. Anderson, J. R., AND Johnstone, J. M.: Fatal intravascular fibrin formation during labour in an iso-immunized doe rabbit. Scot. Med. J., 1: 363 (1956).

6. Astrup, T., Brakman, P., and Nissen, U.: The estimation of fibrinogen. Scand. J. Clin. Lab. Invest., 17: 57 (1965).

7. BАRCZAK, E. M.: Abruptio placentae with hypofibrinogenemia. Obstet. Gynecol., 5: 248 (1955).

8. Barnhart, M. I., Cress, D. C., Henry, R. L., ANd Riddle, J. M.: Influcnce of fibrinogen split products on platelets. Thromb. Diath. Haemorrh., 17: 78 (1967).

9. Barnhart, M. I., and Forman, IV. B.: Purification of fibrinogen. In: L. M. Tocantins and L. A. Kazal: Blood Coagulation, Hemorrhage and Thrombosis, p. 231 (Grune and Stratton, New York, 1964).

10. BeNIRSCHKE, K.: Twin placenta in perinatal mortality. $\mathrm{N}$. $\mathrm{Y}$. J. Med., 61: 1499 (1961).

11. Berglund, G.: The fibrinolytic activity in the newborn. Acta Pediat. Scand., 47:511 (1958).

12. BernsteIn, J., AND MEYer, R.: Congenital abnormalities of urinary system. Renal cortical and medullary necrosis. J. Pediat., 59: 657 (1961).

13. Bigcs, R., And Macfarlane, R. G.: Human Blood Coagulation and Its Disorders (Blackwell Scientific Publications, Oxford, 1962).

14. BLomback, B.: On the properties of fibrinogen and fibrin. Ark. Kemi., 12: 99 (1958).

15. Blomback, B., AND Blomback, Mf.: Purification of human and bovine fibrinogen. Ark. Kemi., 10: 415 (1956).

16. Bloom, A. L., Boyns, A. R., AND Wingfield, J. G.: Obstetric defibrination syndrome with abnormal thrombin-fibrinogen reaction and immunologically reactive altered fibrinogen in serum. Scand. J. Haematol., 5: 26 (1968).

17. BotsverT, P. L.: The streptococcal antifibrinolysin test in clinical use. J. Clin. Invest., 19: 65 (1940).

18. Bolens, M., Lacourt, G., ANd Mottu, T.: Un nouveau cas de transfusion interfoetale surcharge ventriculaire droite et hypocoagulabilite chez la jumelle plethorique; atteinte neurologique chez la jumelle anemique. Schweiz. Med. Wochenschr., 98: 412 (1968).

19. Boyd, J. F.: Disseminated fibrin thromboembolism in stillborns. A histological picture similar to one form of maternal hypofibrinogenemia. J. Obstet. Gynaecol. Brit. Commonw., 73: 629 (1966).

20. Boyd, J. F.: Disseminated fibrin thrombo-embolism among stillbirths and neonatal deaths. J. Pathol. Bacteriol., 90: 65 (1965).

21. Boyd, J. F.: Two possible cases of acquired hypofibrinogenemia in newborns. Surg. Gynecol. Obstet., 106: 176 (1958).

22. Boyd, J. F.: Possible role of placenta in hypofibrinogenemia. Surg. Gynecol. Obstet., 105: 741 (1957).

23. Boyd, J. F.: Disseminated thromboembolism among neonates dying within forty-eight hours of birth. Arch. Dis. Childhood, 42: 401 (1967).

24. Brown, L. J., And Stalker, A. L.: The maternal and foetal microcirculations following placental separation or trauma. J. Pathol. Bacteriol., 90: 53 (1965).

25. Bull, B. S., AND Brain, M. C.: Experimental models of microangiopathic hemolytic anemia. Proc. Roy. Soc. Med., 61: 1134 (1968).

26. Cade, J. F., Hirsil, J., and Mtartin, M.: Placental barrier to 
coagulation factors: Its relevance to the coagulation defect at birth and to hemorrhage in the newborn. Brit. Med. J., 2: 281 (1969).

27. Chaplin, H.: Obscrvations on fibrinolysis in umbilical cord blood. Clin. Sci., 13: 111 (1954).

28. Coopland, A. T.: Blood clotting abnormalitics in relation to preeclampsia. A review. Can. Med. Ass. J., 100: 121 (1969).

29. Coopland, A. T., Israels, E. D., Zipursky, A., and IsRaels, L. G.: The pathogenesis of defective hemostasis in abruptio placentac. Amer. J. Obstet. Gynecol., 100: 311 (1968).

30. Cope, I., And Simmons, E.: The fibrinolytic activity of umbilical cord blood. J. Obstet. Gynaecol. Brit. Commonw., 65: 414 (1958).

31. Edson, J. R., Blaese, R. M., White, J. G., and Krivit, W.: Defibrination syndrome in an infant born after abruptio placenta. J. Pediat., 72: 342 (1968).

32. Fisher, S. H., Schwartz, M., Gottlieb, A., Yoseph, N. B., AND Shapiro, S.: Fibrinolysis, fibrinogen and factor XIII in newborn infants. Thromb. Diath. Haemorrh., 20: 542 (1968).

33. Fitzgerald, T. B., and Jackson, S. H.: Afibrinogenemia in obstetrics. Lancet, $i: 412$ (1956).

34. Fletcher, A. P., Alkjaersic, N., AND Sherry, S.: Maintenance of a sustained thrombolytic state in man. I. Induction and effects. J. Clin. Invest., 38: 1096 (1956).

35. Fresh, J. W., Ferguson, J. H., and Lewis, J. H.: Blood clotting studies in parturient women and the newborn. Obstet. Gynecol., 7: 117 (1965).

36. Goldstein, D. P., AND Reid, D. E.: Circulating fibrinolytic activity-A precursor of hypofibrinogenemia following fetal death in utero. Obstet. Gynecol., 22: 174 (1963).

37. Goodman, L. S., And Gillman, A.: In: The Pharmacological Basis of Therapeutics, p. 1447 (Macmillan, New York, 1965).

38. Hathaway, W. E., Mule, M. M., and Pechet, G. S.: Disseminated intravascular coagulation. Pediatrics, 43: 233 (1969).

39. Hibbard, B. M., and Jeffconte, T. N. A.: Abruptio pla. centac. Obstct. Gynecol., 27: 155 (1966).

40. Hodgkinson, C. P., Luzadre, J. H., Pifer, P. W., Swinehart, Z. A., AND REMP, D. G.: Hypofibrinogenemia and defects of coagulation. Obstet. Gynccol., 5: 465 (1955).

41. Israels, E. D., Rayner, H., Israels, L. G., ANd Zipursky, A.: A microhemagglutination inhibition assay for the quantitation of fibrinogen breakdown products. J. Lab. Clin. Med., 71: 333 (1968).

42. Israels, L. G., Zipursky, A., ANd Sinclair, C.: Factor V levels in the neonatal period. Pediatrics, 15: 180 (1955).

43. JENNY, J., AND DUCKERT, F.: Blood coagulation relations in viable nonasphyxial newborn infants after normal delivery and pregnancy. Gynaecologica, 135: 125 (1963).

44. Kazal, L. A., Amsel, S., Miller, O. P., and Tocantins, L. M.: The preparation and some properties of fibrinogen precipitation from human plasma. Proc. Soc. Exp. Biol. Med., 113: 989 (1963).

45. Kennan, A. L., Bell, W. N., Crekoff, A., and Bachman, C.: The pathologic physiology of the clotting mechanism in eclampsia. Amer. J. Obstet. Gynecol., 74: 1029 (1957).

46. Kowalski, E.: Fibrinogen derivatives and their biologic activities. Seminars Hematol., 5: 45 (1968).

47. Leissring, J. C., AND Vorlisky, L. N.: Disseminated intravascular coagulation in a neonate. Amer. J. Dis. Childhood, 115: 100 (1968).

48. Lipinski, B., ANd Jeljaszewicz, J.: A hypothesis for the pathogenesis of the generalized Shwartzman reaction. J. Infec. Dis., 120: 160 (1969).

49. Lipinski, B., WegrzynowiCZ, Z., BUDZYNSKi, A. Z., KopeC, M., Latallo, Z. S., AND Kowalski, E.: Soluble unclottable complexes formed in the presence of fibrinogen degradation products (FDP) during the fibrinogen-fibrin conversion and their potential significance in pathology. Thromb. Diath. Haemorrh., 17: 65 (1967).

50. Mauer, S. M., ANd Nogrady, M. G.: Renal papillary and cortical necrosis in a newborn infant. J. Pediat., 44: 750 (1969).

51. MIcElfresh, A. E.: Coagulation during the neonatal period. Amer. J. Med. Sci., 240: 771 (1961).

52. McKAY, D. G.: The placenta in experimental toxemia of pregnancies. Obstet. Gynecol., 20: 1 (1962).

53. MCKAY, D. G.: Disseminated Intravascular Coagulation (Hoeber Medical Division, Harper and Row, New York, 1965).

54. McKay, D. G., De Bacalao, E. G., and Sedlis, A.: Platelet adhesiveness in toxemia of pregnancy. Amer. J. Obstet. Gynecol., 90: 1315 (1964).

55. MCKay, D. G., AND Goldenberg, V. E.: Pathogenesis of anatomic changes in experimental toxemia of pregnancy. Obstet. Gynecol., 21: 651 (1963).

56. MCKaY, D. G., Jewetr, J. G., AND ReID, D. E.: Endotoxin shock and the generalized Shwartzman reaction in preg. nancy. Amer. J. Obstet. Gynecol., 78: 546 (1959).

57. McKay, D. G., Merrill, S. J., Weiner, A. E., Hertic, A. J., AND REID, D. E.: The pathological anatomy of eclampsia, bilateral renal cortical necrosis, pituitary necrosis and other acute fatal complications of pregnancy and its possible relationship to generalized Shwartzman reaction. Amer. J. Obstet. Gynecol., 66: 507 (1953).

58. McKay, D. G., AND Wong, T. C.: The effect of bacterial cndotoxin on the placenta of the rat. Amer. J. Pathol., 42: 357 (1963).

59. Miller, S. P., and Sanchez-Avalos, J.: Degradation of fibrinogen by proteolytic enzymes. II. Effect on the products of coagulation. Thromb. Diath. Haemorrh., 20: 420 (1968).

60. MOE, N., AND J $\phi$ RGENSEN, L.: Fibrin deposits on the syncytium of the normal human placenta: evidence of their thrombo. genic origin. Acta Path. Microbiol. Scand., 72: 519 (1968).

61. Moore, C. M., McAdam, A. J., And Sutherland, J.: Intrauterine intravascular coagulation. J. Pediat., 74: 523 (1969).

62. Morris, R. H., Vassalli, P., Beller, F. K., ANd McCluskey, R. T.: Immunofluorescent studies of renal biopsies in diag. nosis of toxacmia of pregnancy. Obstet. Gynecol., 24: 32 (1964).

63. Nossel, H. L., Lanzkowsky, P., Levy, S., Mibashon, R., AND HANSEN, J.: A study of coagulation factor levels in women during labour and in their newborn infants. Thromb. Diath. Haemorrh., 16: 185 (1966).

64. Nussenziweig, V., Seligman, M., Pelmont, J., and Grabar, P.: Les products de degradation du fibrinogene humaine par la plasmine. II. Etude immunologique mise en evidence d'anticorps antifibrinogene notif possedant des specifites differentes. Ann. Inst. Pasteur, 100: 490 (1961).

65. Page, E. W., Fulton, L. D., and Glendening, M. B.: The cause of the blood coagulation defect following abruptio placentac. Amer. J. Obstet. Gynccol., 61: 1116 (1951).

66. Phillips, L. L., and Skrodelis, V.: A comparison of the fibrinolytic enzyme system in maternal and umbilical cord blood. Pediatrics, 22: 715 (1958). 
67. Phillips, L. L., Skrodelis, V., ANd King, T. A.: Hypofibrinogenemia and intrauterine fetal deaths. Amer. J. Obstet. Gynecol., 89: 903 (1964).

68. Pritchiard, J. A.: Treatment of defibrination syndrome of pregnancy. Mod. Treat., 5: 401 (1968).

69. Pritchard, J. A.: Abruptio placentae and hypofibrinogenemia. Amer. J. Obstet. Gynecol., 76: 347 (1958).

70. Pritcilard, J. A.: Fetal death in utero. Obstet. Gynecol., 14: 573 (1959).

71. Pritchard, J. A.: Hemostatic defects in pregnancy. Amer. J. Obstet. Gynecol., 72: 946 (1956).

72. Pritchard, J. A., ANd Brekken, A. L.: Clinical and laboratory studies on severe abruptio placentae. Amer. J. Obstet. Gynecol., 97: 681 (1967).

73. Pritchard, J. A., and Ratnoff, O. D.: Studies of fibrinogen and other hemostatic factors in women with intrauterine death and delayed delivery. Surg. Gynecol. Obstet., 101: 467 (1955).

74. Pritchard, J. A., Ratnoff, O. D., and Weisman, R., JR.: Hemostatic defects and increased red blood cell destruction in pre-eclampsia and eclampsia. Obstet. Gynecol;; 4: 159 (1954).

75. Pritchard, J. A., Weisman, R., JR., Ratnoff, O. D., and VosBURGH, G. J.: Intravascular hemolysis, thrombocytopenia and other hematologic abnormalities associated with severe toxemia of pregnancy. New Engl. J. Med., 250: 89 (1954).

76. Pritcilard, J. A., ANd Wright, M. R.: Pathogenesis of hypofibrinogenemia in placental abruption. New Engl. J. Med. 261: 218 (1959).

77. Proctor, R. R., ANd Rapaport, S. I.: The partial thromboplastin time with kaolin. Amer. J. Clin. Pathol., 36: 212 (1961).

78. Quick, A. J.: On quantitative estimation of prothrombin. Amer. J. Clin. Pathol., 15: 560 (1945).

79. Quick, A. J., AND STEFANini, M.: The concentration of the labile factor of the prothrombin complex in human, dog and rabbit blood; its significance in the determination of prothrombin activity. J. Lab. Clin. Med., 33: 819 (1948).

80. Quie, P. G., AND Wannamaker, L. W.: The plasminogenplasmin system of newborn infants. Amer. J. Dis. Childhood, 100: 836 (1960).

81. Ratnoff, O. D., And Menzie, C.: A new method for the determination of fibrinogen in small samples of plasma. J. Lab. Clin. Med., 37: 316 (1951).

82. Ratnoff, O. D., Pritchard, J. A., and Colopy, J. E.: Hemorrhagic states during pregnancy. New Engl. J. Med., 253: 97 (1955).

83. Ratnoff, O. D., Pritchard, J. A., And Colopy, J. E.: Hemorrhagic states during pregnancy. New Engl. J. Med., 253: 63 (1955).

84. RatNoff, O. D., AND Vosburgh, G. J.: Observations on clotting defect in amniotic fluid embolism. New Engl. J. Med., 247: 970 (1952).

85. Rayner, H., Paraskevas, F., Israfls, L. G., and Israels, E. D.: Fibrinogen breakdown products: Identification and assay in serum and urine. J. Lab. Clin. Med., 74: 586 (1969).

86. ReID, D. E., WeINER, A. E., AND RoBY, C. C.: Intravascular clotting and afibrinogenemia-The presumptive lethal factors in the syndrome of amniotic fluid embolism. Amer. J. Obstet. Gynecol., 66: 465 (1958).
87. Reid, D. E., Weiner, A. E., AND Roby, C.: Incoagulable blood in severe premature separation of placenta. Amer. J. Obstet. Gynecol., 66: 457 (1953).

88. Reid, D. E., Weiner, A. E., ANd Roby, C. C.: Presumptive amniotic fluid infusion with resultant postpartum hemorrhage due to afibrinogenemia. J. Amer. Med. Ass., 152: 227 (1953).

89. Reid, D. E., Weiner, A. E., Roby, C., And Diamond, L. K.: Maternal afibrinogenemia with long standing intrauterine fetal death. Amer. J. Obstet. Gynecol., 66: 500 (1953).

90. Reisman, L. E., AND Pathak, A.: Bilateral renal cortical necrosis in the newborn. Amcr. J. Dis. Childhood, 111: 541 (1966).

91. Rosner, F., AND RUbenberg, M. L.: Erythrocyte fragmentation in consumption coagulopathy. New Engl. J. Med., 280: 219 (1969).

92. SCHNEIDER, C. L.: Disseminated intravascular coagulation: Thrombosis versus fibrination. Thromb. Diath. Haemorrh., Suppl., 36: 1 (1969).

93. SCHNeIder, C. L.: Complications of late pregnancy in rabbits induced by experimental placental trauma. Surg. Gynecol. Obstet., 90: 613 (1950).

94. SChNeider, C. L.: Fibrin embolism (disseminated intravascular coagulation) and the actiology of eclampsia. J. Obstet. Gynaecol. Brit. Commonw., 58: 538 (1951).

95. SCHNeIDER, C. L.: The active principle of placental toxin: Thromboplastin-Its inactivator in blood; antithrombo. plastin. Amer. J. Physiol., 149: 123 (1947).

96. SChNeider, C. L.: Rupture of basal (decidual) plate in abruptio placentac. A pathway of autoextraction from decidua into the maternal circulation. Amer. J. Obstet. Gynecol., 63: 1078 (1952).

97. SCIINEIDER, C. L.: Mechanism of production of acute fibrinogen deficiencies. In: L. M. Tocantins: Progress in Hematology, Vol. 1, p. 202 (Grune \& Stratton, New York, 1956).

98. Schineider, C. L.: "Fibrin embolism" (disseminated intravascular coagulation) with defibrination as one of the end results during placenta abruptio. Surg. Gynecol. Obstet., 92: 27 (1951).

99. Scort, J. S.: Coagulation failure in obstetrics. Brit. Med. Bull., 24: 32 (1968).

100. Sherry, S.: Fibrinolytic activity of streptokinase activated human plasmin. J. Clin. Invest., 33: 1054 (1954).

101. Sherry, S., Fletcher, A. P., and Alkjaersig, N.: Fibrinolysis and fibrinolytic activity in man. Physiol. Rev., 39: 343 (1959).

102. SLuder, H. M., AND Lock, F. R.: Sudden maternal dcath associated with amniotic fluid embolism. Amer. J. Obstet. Gynecol., 64: 118 (1952).

103. Stamler, F. W.: Toxemia of pregnancy induced by progesterone in the rats. Fed. Proc., 20: 408 (1961).

104. Stark, C. R., Abramson, D., and Erkan, V.: Intravascular coagulation and hyaline membrane disease of the newborn. Lancet, $i$ : 1180 (1968).

105. Valentine, G. H.: Fibrinolytic discase in both mother and newborn. Obstet. Gynecol., 12: 462 (1958).

106. Vassalli, P., ANd McCluskey, R. T.: The coagulation process and glomerular disease. Amer. J. Med., 39: 179 (1965).

107. Verstraete, M.: L'action hemostatique du liquide amniotique. Rev. Belg. Pathol., 21: 309 (1952).

108. Verstraete, M., and Vermylen, J.: Acute and chronic 
"defibrination" in obstetrical practice. Thromb. Diath. Haemorrh., 20: 444 (1968).

109. Vigilante, M., and BeirRinger, F. R.: Afibrinogenemia: Report of a case associated with long standing fetal death in utero and $\mathrm{Rh}$ isosensitization. Obstet. Gynecol., 6: 434 (1955).

110. von Felton, A., and Straub, P. W.: Coagulation studies of cord blood with special reference to "fetal fibrinogen." Thromb. Diath. Haemorrh., 22: 273 (1969).

111. Weiner, A. E., Reid, D. E., ANd Roby, C. C.: Coagulation defects associated with premature separation of the normally implanted placenta. Amcr. J. Obstet. Gynecol., 60: 379 (1950).

112. WeIner, A. E., ReID, D. E., AND Roby, C. C.: Hemostatic activity of amniotic fluid. Science, 110: 190 (1949).

113. Weiner, A. E., Reid, D. E., Roby, C. C., and Diamond, L. K.: Coagulation defects with intrautcrine death from $\mathrm{Rh}$ isosensitization. Amer. J. Obstet. Gynecol., 60: 1015 (1950).

114. Wilner, G., Phillips, L. L., and McKay, D. G.: Platelet damage in experimental toxemia of pregnancy. Obstet. Gynecol., 23: 182 (1964).

115. WOLF, P., AND WALTON, K. W.: Investigation of a quantita- tive anomaly encountered in the assay of fibrinogen by im. munodiffusion. Immunology, 8: 6 (1965).

116. Wong, T. C.: A study on the generalized Shwartzman reaction in pregnant rats induced by bacterial endotoxin. Amer. J. Obstet. Gynecol., 84: 786 (1962).

117. Zilliacus, H., Otrelin, A. M., and Mattsson, T.: Blood clotting and fibrinolysis in human foetuses. Biol. Neonatorum, 10: 108 (1966).

118. Trasylol, Farbenfabriken Bayer AG., Leverkusen, Germany.

119. We wish to express our thanks to Mrs. L. Baxter, Miss L. Bangard, Miss J. Routly, and Mr. B. Russell for technical assistance, and to Dr. F. Wong for assistance with surgical preparations.

120. Dr. A. J. Bishop, Centennial Fellow, Medical Research Council of Canada.

121. Supported by grants from the Manitoba Heart Foundation and the Medical Research Council of Canada.

122. Requests for reprints should be addressed to: E. D. Israels, M.D., Manitoba Institute of Cell Biology, 700 Bannatyne Avenue, Winnipeg 3, Manitoba, Canada.

123. Accepted for publication April 28, 1970 